\title{
Behavioural public administration: a systematic review on the effects of cognitive biases on public adminstration decisions
}

\author{
Administração pública comportamental: uma revisão sistemática sobre os efeitos dos viéses \\ cognitivos nas decisões de administração pública
}

\author{
Fabio Takeji Iwasa ${ }^{1(D)}$, Fernando Carvalho de Almeida ${ }^{2}$ (D) \\ ${ }^{1}$ Faculdade de Economia, Administração e Contabilidade da Universidade de São Paulo (USP), Brasil, Doutorando em \\ administração (FEA/USP), e-mail: takeji@usp.br \\ 2 Faculdade de Economia, Administração e Contabilidade da Universidade de São Paulo (USP), Brasil, Doutor em \\ Administração (Université Piere Mendes France - Grenoble 2), professor associado (USP) e professor convidado de \\ Universidades Francesas (IAE de Nancy, IAE de Grenoble, IAE de Aix en Provence), e-mail: fcalmeida@usp.br
}

\begin{abstract}
Public administration and psychology can dialogue by outlining a distinct approach in public administration that integrates both fields of study: behavioral public administration. The behavioral public administration can be beneficial for practitioners, such as policy makers, public managers, and public professionals, by the development of usable knowledge. This paper aims to elaborate a systematic literature review of the findings on the application of the behavioral economics principles on the public administration and the effects of cognitive biases from the behavioral economics perspectives on public managerial decisions. It will provide a comprehensive overview of the problems that could emerge from this decision-making process. The main contribution that is objected through this research is consolidate the current state of the art on the cognitive biases studies within Public Administration and identify the application and theoretical knowledge gaps that can provide new research opportunities.
\end{abstract}

Keywords: Public Administration. Behavioral Economics. Cognitive Bias.

\section{RESUMO}

A administração pública e a psicologia podem dialogar delineando uma abordagem distinta na administração pública que integra os dois campos de estudo: administração pública comportamental. A administração pública comportamental pode ser benéfica para os profissionais, como formuladores de políticas, gestores públicos e profissionais públicos, pelo desenvolvimento de conhecimento utilizável. Este artigo tem como objetivo elaborar uma revisão sistemática da literatura dos achados sobre a aplicação dos princípios da economia comportamental na administração pública e os efeitos dos vieses cognitivos da perspectiva da economia comportamental nas decisões gerenciais públicas. Ele fornecerá uma visão abrangente dos problemas que podem surgir desse processo de tomada de decisão. A principal contribuição que se objetiva com esta pesquisa é consolidar o estado da arte atual sobre os estudos de vieses cognitivos na Administração Pública e identificar as lacunas de aplicação e de conhecimento teórico que podem proporcionar novas oportunidades de pesquisa.

Palavras-chave: Administração Pública. Economia Comportamental. Viés Cognitivo. 


\section{INTRODUCTION}

According to Camerer, Loewenstein and Prelec (2005) from the last decades, economics has begun to import insights from psychology. The term "Behavioral economics" is now a prominent fixture on the intellectual landscape and has spawned applications to topics in economics, such as finance, game theory, labor economics, public finance, law, and macroeconomics. It has evolved from the psychology branch of behavioral decision research to a topic itself, including important insights from neurosciences and cognitive sciences in relation to the economic environment. The authors also state that the foundations of economic theory were constructed assuming that details about the functioning of the brain's black box would not be known, what is now being unveiled by the neuroscience.

On the public administration, behavioral sciences suggest that public servants' judgments may be systematically biased under certain circumstances (BELLE; CANTARELLI, 2018). As for public organizations and their managers, the authors indicate that managerial decisions may be highly dependent on systematic patterns of deviation from rationality. Taking action on public policy means public managers must overcome not only these complexities in their environment but also their own cognitive limitations and moral impasses. Influencing public managers' decision processes from a more informed assessment of cognitive biases and libertarian paternalism has the potential to improve effectiveness through strategic choices that shape goal attainment (BATTAGLIO et al., 2019).

Alm and Sheffrin (2017) state that most approaches to analyzing behavior have traditionally been based on variants of the standard economic model of behavior, in which an individual is assumed to be a fully rational, self-controlled, and maximizing decision-maker the homo economicus, as called by Thaler and Sunstein (2009). However, it is increasingly recognized that individuals do not always behave in ways that are consistent with this standard model - they are indeed homo sapiens. The concept of the Behavioral economics can be traced to the applications, methods and evidence from other social sciences like anthropology, and specially psychology to economics. At its core is the belief that increasing the realism with which individual behavior is seen will improve the ability to predict behavior and to devise policies. There is a growing acceptance that, contrary to the standard neoclassical approach: "individuals are affected by the ways in which choices are "framed" (e.g., "reference points", gains versus losses, "loss aversion", "risk-seeking behavior", "status quo bias"), they face limits on their ability to compute (e.g., "bounded rationality", "mental accounting"), they 
systematically misperceive, or do not perceive at all, the true costs of actions (e.g., "fiscal illusion", "saliency", "overweighting" of probabilities), they face limits on their "self-control" (e.g., "hyperbolic discounting", Christmas savings clubs, automatic enrollment programs), they are motivated not simply by self-interest, but also by notions of fairness, altruism, reciprocity, empathy, sympathy, trust, guilt, shame, morality, alienation, patriotism, social customs, social norms, and many other objectives, and they are influenced by the social context in which they inhabit, and the process by which decisions are made. "(ALM; SHEFFRIN, 2017).

Grimmelikhuijsen et al. (2017) deepen the dialogue between public administration and psychology by outlining a distinct approach in public administration that integrates both fields of study: behavioral public administration. The behavioral public administration can be beneficial for practitioners, such as policy makers, public managers, and public professionals, by the development of usable knowledge. Also, Battaglio et al. (2019) states that understanding how public decisions may predictably go wrong is imperative to improve the architecture of public organizations and services, and the behavioral science can help illuminate the gap between the how people should behave and how they actually behave, thus moving beyond traditional models of full rationality in decision making. Belle and Cantarelli (2018) demonstrated that managerial decisions are highly dependent on systematic patterns of deviation from rationality.

Assuming that the behavioral deviation from rationality can occur as a regular threat on the human behavior, we aim with this paper report through a systematic review the findings on the application of the behavioral economics principles on the public administration. A second step is to analyze researches that identify the effects of cognitive biases from the behavioral economics perspectives on public managerial decisions. It will provide a comprehensive overview of the problems that could emerge from this decision-making process.

\section{METHODOLOGY}

According to Snyder (2019) a literature review can broadly be described as a systematic way of collecting and synthesizing previous research. An effective and well conducted review as a research method creates a firm foundation for advancing knowledge and facilitating theory development. And by integrating findings and perspectives from many empirical findings, a literature review can address research questions with a power that no single study has. The systematic review is a research method and process for identifying and critically appraising 
relevant research, as well as for collecting and analyzing data from said research (LIBERATI, 2009).

\subsection{SEARCH STRATEGY}

The first step on the systematic review is the determine the appropriate search terms in order to primarily assess the research problem. After this definition, the second step is to conduct a systematic search in three relevant scientific databases: Web of Science, Scopus, which are according to Wang and Waltman (2016) the database with most accurate classification systems, and Science Direct, that according to Tober (2011) presents the most effective search engine for an overview of a topic. To ensure that the most recent studies were included, and the search strategy fulfilled the objective of this paper, it was conducted contemplating articles as recent as June 2020. The search terms used were 'behavioral', 'public administration (management)'. No language nor date restrictions were applied.

\begin{tabular}{|c|c|c|}
\hline Database & Search Criteria & Results \\
\hline Science Direct & $\begin{array}{c}\text { Title, abstract, keywords: "Behavioral" AND ("Public Administration" } \\
\text { OR "Public Management") }\end{array}$ & 89 \\
\hline Scopus & $\begin{array}{c}\text { (TITLE-ABS-KEY(Behavioral ) AND TITLE-ABS-KEY("public } \\
\text { administration" OR "Public management")) AND ( LIMIT-TO ( } \\
\text { DOCTYPE,"ar" ) ) }\end{array}$ & 201 \\
\hline Web of Science & $\begin{array}{l}\text { Você pesquisou por: TÓPICO: ("Behavioral") AND TÓPICO: ("Public } \\
\text { administration" OR "Public management") } \\
\text { Refinado por: TIPOS DE DOCUMENTO: ( ARTICLE ) }\end{array}$ & 111 \\
\hline
\end{tabular}

Source: research data.

\subsection{SELECTION CRITERIA}

The inclusion criteria of the papers intended to address the primary research question, which are the contributions and studies of behavioral economics principles that were empirically applied on the public administration field. It included practical concepts of the behavioral sciences applied on public policies, and on the change of behavior of the citizen towards a beneficial social welfare to the general society. The intent for this research was to include the broadest view of the behavioral economics concepts application possibilities on real 
world cases, showing opportunities of replications or gaps that could be studied in future research.

From the total of 401 papers, 4 were eliminated for being duplicated, and a selection criterion was applied. From the qualitative assessment that included the analysis of the abstracts, only articles that encompassed any kind of behavioral science applied on the domain of public administration, employees, services and policies were selected.

\subsection{DATA EXTRACTION AND SYNTHESIS}

Following the systematic search, a screening of titles and abstracts was done to identify their potential inclusion in the review. The following data were extracted into Tables in the first screening: authors, publication year, research objectives, methodology and major results. The extracted data file was checked for completeness and accuracy and a final data collection was made. According to this criterium, a final list with 48 papers were selected.

In order to define and categorize the articles, after the selection performed on the previous item, they were categorized in different epistemological axis utilizing the lexical search tool on the MAXQDA Analysis Pro 2020 software, that counted the occurrence of the qualificator terms within the text of the articles.

\section{RESULTS}

\subsection{DESCIPTIVE ANALYSIS RESULTS}

From the final list of 48 papers, Figure 1 shows the evolution of the timeline of the publishing date. 
Figure 1 - Publications per year

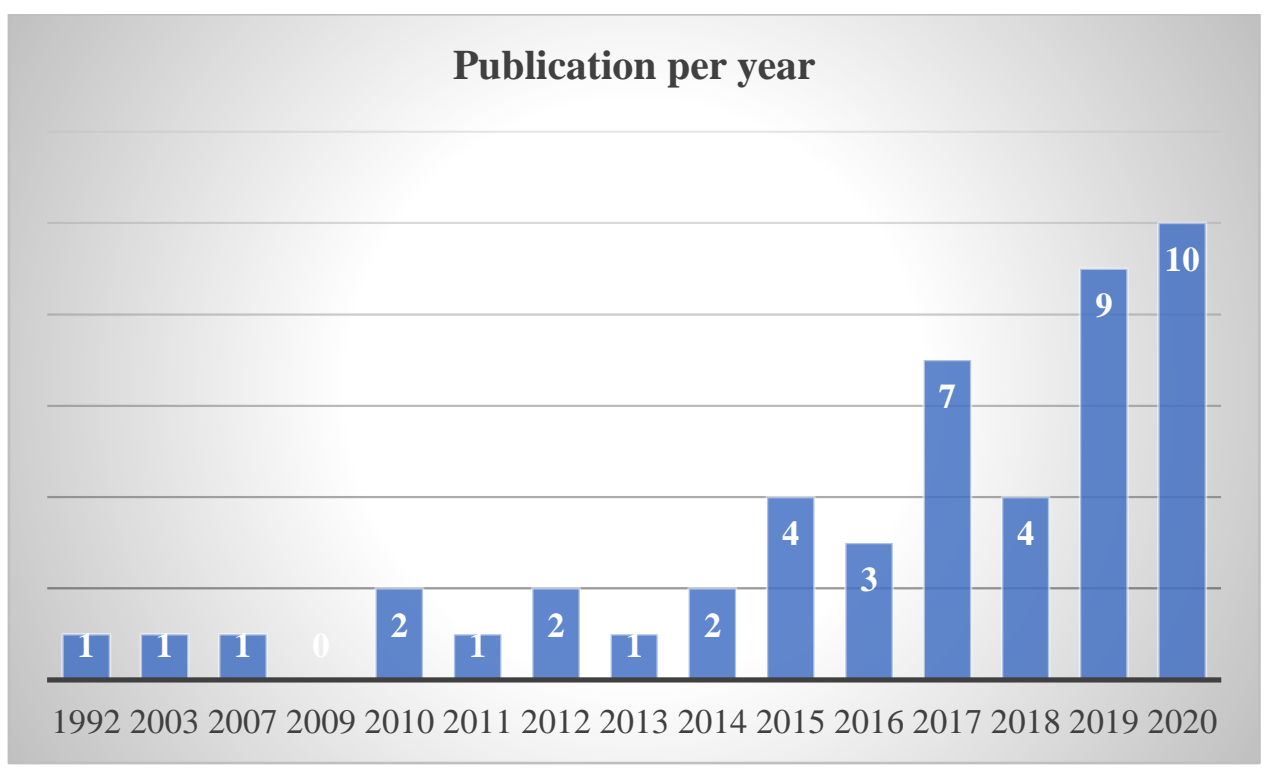

Source: research data.

Table 2 shows the publications where the articles were published, with a great dominance of articles published on Public Administration Review.

Table 2 - Quantity of articles per publication

\begin{tabular}{l|l}
\hline Publication title & \\
\hline Public Administration Review & 22 \\
\hline $\begin{array}{l}\text { Journal of Public Administration Research and } \\
\text { Theory }\end{array}$ & 7 \\
\hline Public Administration & 4 \\
\hline Administration \& Society & 2 \\
\hline Public Performance \& Management Review & 2 \\
\hline International Public Management Journal & 2 \\
\hline Cognitive Systems Research & 1 \\
\hline Computers in Human Behavior & 1 \\
\hline $\begin{array}{l}\text { Admernance-an International Journal of Policy } \\
\text { Public Integrity }\end{array}$ & 1 \\
\hline Public Management Review Instion and Institions & 1 \\
\hline Regulation and Governance & 1 \\
\hline Research Policy & 1 \\
\hline Revista Eletronica De Estrategia E Negocios-Reen & 1 \\
\hline $\begin{array}{l}\text { Voprosy Gosudarstvennogo I Munitsipalnogo } \\
\text { Upravleniya-Public Administration Issues }\end{array}$ & 1 \\
\hline
\end{tabular}

Source: research data.

Revista Expectativa, Toledo/PR, v.20, n. 1, p. 97-111, jan./mar., 2021. 
The mapping knowledge domain (MKD) methods provide a new way to conduct a literature survey exploring disciplinary development status, research frontiers,r research hotspots, and systematic reviews. Mapping the knowledge domain is a kind of image which shows the development process and structural relationship on the scientific knowledge (ZOU; YUE; VU, 2018). In order to create this map, the VOSviewer network tool was used. The complete articles texts were imported in the software in order to provide the network map with the most relevant terms and its relationship within themes.

Using the VOSviewer network tool from the most relevant words presented on the articles, the result is presented in Figure 2:

Figure 2 - Network map of relevant terms

disclosure biase

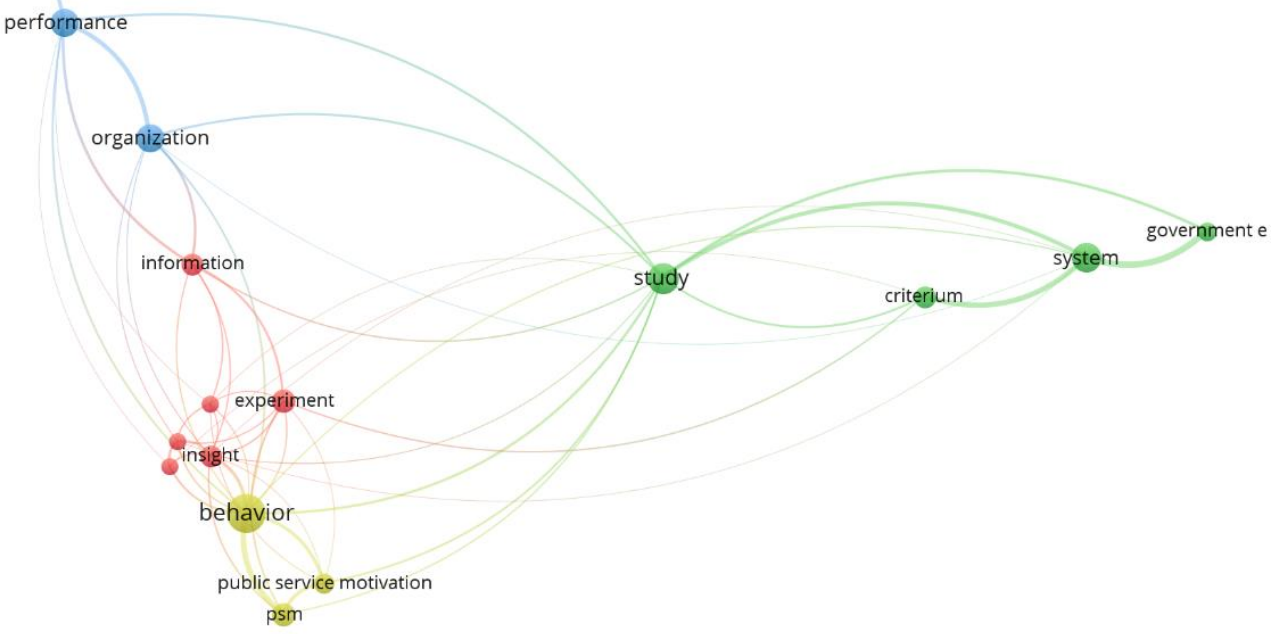

莴 VOSviewer

Source: research data.

We can conclude from the collected articles that the behavior and motivations are responsible for the action, the performance of the service or employee. And this performance output can be influenced by insights, experiments, information and nudges. This map can constitute a conceptual map that can lead to the classification of the papers within the categories of motivated behaviors (cognitive bias), that can be regulated or controlled by insights (nudges) and lead to an action (human resource or service performance).

Using the search tool from the MAXQDA Analysis Pro 2020 software, using the terms above, we could classify the articles on these three categories. 
The motivated behavior had the influence of cognitive bias on decision making (PERRY; HONDEGHEM; WISE, 2010), (BATTAGLIO et al., 2019), (BELLE; CANTARELLI, 2018), (MEYER-SAHLING; MIKKELSEN; SCHUSTER, 2019), (JONES, 2003), and it influence how the public server interacts with the citizens (CHRISTENSEN et al., 2020) and how them can act in self-interest and eventually act with dishonesty (ZAMIR; SULITZEANU-KENAN, 2018), (OLSEN et al., 2019) and (BOLOGNESI; PFLIEGER, 2019). The cognitive bias from the population side can lead to wrong evaluation of the performance of a public service (HONG et al., 2017) as does the conformity towards prevailing public opinions and preexisting blame influence the perception of the citizens of a public service (SIEVERT et al., 2020). Increasing awareness about program screening processes may be beneficial as it improves views toward welfare programs. However, public officials should consider potential trade-offs, such as discouraging applications (KEISER; MILLER, 2020).The overconfidence of the bureaucratic experts can influence in risk-taking public policy choices (LIU; STOUTENBOROUGH; VEDLITZ, 2017). The future of the public administration should take advantage of the cognitive sciences in order to provide better results (JONES, 2017) and (GRIMMELIKHUIJSEN et al., 2017) with some key methodological issues that behavioral public administration scholars need to consider and address as the use of experiments becomes more common in public administration research (HASSAN; WRIGHT, 2020).

As a second conceptual axis, we have the intervention within the behavior of a policy actor, in the form of information, insights, experiments or nudges, in order to change the behavior and control the cognitive biases that can cause misjudging or irrational think patterns on decision making. Error in judgement caused by cognitive biases can be traced and corrected with the behavioral approach as a framework to reflect on ethical beliefs and practices (BOWMAN, 2018). International experience of using behavioral tools for increasing the effectiveness of public administration and possible prospects of their implementation in the Russian rulemaking practice is analyzed (GOLODNIKOVA; TSYGANKOV; YUNUSOVA, 2018).

Potential barriers to compliance with public policies by individuals and businesses can and should be anticipated in the design of policies as well as during their implementation. Strategies to increase compliance, including the use of leverage points and secondary targets, adjusting for unanticipated behavioral responses, and employing long-term, multiphase strategic management of behavior change initiatives (WEAVER, 2015). Knowledge of behavioral insights also can help regulators design a choice architecture that frames individual 
decisions to encourage welfare-enhancing choices, it may help governments understand and design institutions to counter cognitive biases in regulators that contribute to deviations from public interest policies (DUDLEY; XIE, 2020). Public administrators also can use behavioral science techniques to increase compliance with written requests and, in turn, increase effectiveness (FAULKNER et al., 2019).

In terms of domestic security warning, if the public responds appropriately to warnings, and takes proper preventative actions, threats are mitigated, and security improves. In the context of public security, the effectiveness of security warnings is influenced by how citizens and governmental employees such as security staff and police officers behave and react to those warnings. Optimal policies for warning issuance are sensitive to two major behavioral characteristics of the society: how fast people might start ignoring warnings, and how adversaries perceive such ignorance (GHAFFARZADEGAN; ANDERSEN, 2012).

In a neoliberal administrative state, in an absence of policy guidance, potential nudge responses are a justifiable call for action to protect the public welfare (KASDAN, 2019) and act on change health behaviors (VLAEV et al., 2016).

However, nudges should be frequently assessed in order to prove its consistency and validity (WEIMER, 2020), since libertarian paternalism requires policies to protect individual liberty, to be focused specifically upon improving the welfare of those towards whom the intervention is targeted, and in practice, however, many of the interventions that are being advocated as nudges do not meet all of these criteria (OLIVER, 2015).

In order to deal with the risk aversion on the benefits of public services, an integrated strategy that combines collaboration, complementary process and communication innovations, and an active management strategy to support innovation is the most effective method for 'lowrisk-averse' small agencies and 'high-risk-averse' larger agencies to obtain high benefits from either novel or incremental service innovations (TORUGSA; ARUNDEL, 2017).

The third axis refers to the performance influenced by the interventions on behavior and cognitive bias. Employee empowerment intervention can be used to improve job satisfaction, organizational commitment, innovativeness, and performance (FERNANDEZ; MOLDOGAZIEV, 2013). About the performance feedback, employees on public organizations present the negative bias, that treat only to satisfy the minimum performance standard rather than excel it (HONG, 2019). Providing performance feedback improves managerial quality, but this impact is observed only among low-performing organizations, and the impact of performance feedback is greater if organizations operate in electorally competitive jurisdictions 
(HONG; KIM; SON, 2020). The study of organizational learning from performance information in the public sector can benefit from making explicit use of behavioral models of information processing. Such models focus on the reported level of performance and the knowledge this conveys to decision makers about their organization (NIELSEN, 2014). Administrative reforms communicate an image of how public servants should behave. Even if it is difficult to directly monitor that form of behavior implied by the reform, we argue that it is important to study such behavior because it represents a form of accountability to normative expectations about public employees. In our current era, administrative reforms call for public employees to actively use performance data (MOYNIHAN; HAWES, 2012). New empirical evidence suggests that service performance is shaped by the strategies adopted by public organizations and the networking behavior of public managers. Strategy processes based on rational planning offer long-run positive effects on public services, as does a strategic proactive stance (WALKER et al., 2010).

Other factors like physical workplace have a significant impact on affective, behavioral, and performance outcomes in the public organization (KIM, 2014), as well as the role of religion and spirituality in the public workplace, impacts organizational performance, ethical behavior patterns, decision making, and the personal spiritual health of employees (KING, 2007).

Public employees are confronted with various pressures, such as increased work demands and the need to implement controversial policies. It was firstly found that work alienation results in less work effort and more intention to leave. Secondly, policy alienation negatively impacts behavioral support for a policy and the intention to implement (TUMMERS et al., 2015). Performance Evaluation, associated with cognitive biases, has been addressed in Public Administration. There is the evidence of the real concern of behavioral insights to improve public policies and that individuals make more negative assessments of organizations if they are presented as public, and not as private, the "Public Antisector" bias (BUGALHO; SCHNORRENBERGER, 2020).

The government strategies for enhancing organizational performance have sought to reduce the amount of red tape public employees face. The individuals will judge a rule to be red tape based on information conveyed second-hand regarding the rule-breaking behavior of others (DAVIS; PINK-HARPER, 2016).

There is also strong evidence that motivation, measured as self-sacrifice, is higher among bureaucrats in decentralized systems led by nongovernmental organizations compared with 
those led by municipal governments or associations. Additionally, the evidence suggests that higher motivation is related to changes in the composition of staff rather than socialization or changes among existing staff (ZARYCHTA; GRILLOS; ANDERSSON, 2020).

Providers of public services are expected to act upon their motivation to deliver public service with the purpose of doing good for others and society. However, that public service motivation is malleable and that public service motivation is a particular workable lever in changing public service behaviors among shorter-tenured public service providers (JENSEN; ANDERSEN, 2015). A positive link is found between that public service motivation and prosocial behavior. This relationship is moderated by the behavior of other group members: high- that public service motivation people act even more prosocially when the other members of the group show prosocial behavior as well, but they do not do so if the behavior of other group members is not prosocial (ESTEVE et al., 2016). Motivation to benefit individual recipients of public services (user orientation) can conflict with classic public service motivation linked to the interest of a collective entity (JENSEN; ANDERSEN, 2015).

\section{FINAL CONSIDERATIONS}

Literature reviews play an important role as a foundation for all types of research, serving as a basis for knowledge development, creating guidelines for policy and practice, providing evidence of an effect, and engendering new ideas and directions for a particular field. As such, they serve as the grounds for future research and theory.

The research presented a widespread view on the field of Behavioral Public Administration, and the increasing demands and opportunities of the combined knowledge from the Behavioral Economics on Public and Governmental affairs, especially when it is considered the number of studies published in the last three years.

The studies show how the behaviors are influenced by cognitive bias that no human being is free from suffer. As the decisions of public managers have huge impact on the society and population, so has the bounded rationality that the decision makers and citizens can be affected. Strategies of controlling or minimize these distortions is being applied in the form of interventions like debiasing and nudges. These interventions can affect directly the performance of the Human Resources and actors of the public service. The research shows that there is a vast opportunity to be explored on applying the knowledges of Behavioral Economics on the Public Administration, specially in Brazil, where few experiences are being made in the area. 


\section{REFERENCES}

ALM, James; SHEFFRIN, Steven M. Using Behavioral Economics in Public Economics. Public Finance Review, [S. l.], v. 45, n. 1, p. 4-9, 2017. DOI: 10/ggfwvh.

BATTAGLiO, Jr., R. P.; BELARDINELli, P.; BELLÉ, N.; CANTARELLI, P. Behavioral Public Administration ad fontes: A Synthesis of Research on Bounded Rationality, Cognitive Biases, and Nudging in Public Organizations. Public Administration Review, [S. l.], v. 79, n. 3, p. 304-320, 2019. DOI: 10/gfrmcr.

BELLE, Nicola; CANTARELLI, Paola. Randomized Experiments and Reality of Public and Nonprofit Organizations: Understanding and Bridging the Gap. Review of Public Personnel Administration, [S. l.], v. 38, n. 4, p. 494-511, 2018. DOI: 10/gf5r4x.

BOLOGNESI, T.; PFLIEGER, G. In the shadow of sunshine regulation: Explaining disclosure biases. Regulation and Governance, [S. l.], 2019. DOI: 10/gg5zq9. Disponível em: https://www.scopus.com/inward/record.uri?eid=2-s2.0-

$85074023194 \&$ doi $=10.1111 \% 2$ frego.12286\&partnerID=40\&md5=1a110cb9ca01cc4f907a22f $376 \mathrm{~d} 8 \mathrm{cb} 64$.

BOWMAN, J. S. Thinking about Thinking: Beyond Decision-Making Rationalism and the Emergence of Behavioral Ethics. Public Integrity, [S. l.], v. 20, p. S89-S105, 2018. DOI: $10 / \operatorname{gg} 5 \mathrm{zq} 6$.

BUGALHO, F. M.; SCHNORRENBERGER, D. Performance evaluation associated with cognitive viesis in public administration: insights of international literature. Revista Eletronica De Estrategia E Negocios-Reen, [S. l.], v. 13, n. 1, p. 184-206, 2020. DOI: 10.19177/reen.v13e02020184-206.

CAMERER, Colin; LOEWENSTEIN, George; PRELEC, Drazen. Neuroeconomics: How Neuroscience Can Inform Economics. Journal of Economic Literature, [S. l.], v. 43, n. 1, p. 9-64, 2005. DOI: 10/bct5zc.

CHRISTENSEN, J.; AARØE, L.; BAEKGAARD, M.; HERD, P.; MOYNIHAN, D. P. Human Capital and Administrative Burden: The Role of Cognitive Resources in Citizen-State Interactions. Public Administration Review, [S. l.], v. 80, n. 1, p. 127-136, 2020. DOI: 10.1111/puar.13134.

DAVIS, R. S.; PINK-HARPER, S. A. Connecting Knowledge of Rule-breaking and Perceived Red Tape: How Behavioral Attribution Influences Red Tape Perceptions. Public Performance \& Management Review, [S. l.], v. 40, n. 1, p. 181-200, 2016. DOI: 10/gg5zq5.

DUDLEY, S. E.; XIE, Z. Designing a Choice Architecture for Regulators. Public Administration Review, [S. l.], v. 80, n. 1, p. 151-156, 2020. DOI: 10/gg26dp.

ESTEVE, M.; URBIG, D.; VAN WITTELOOSTUIJN, A.; BOYNE, G. Prosocial Behavior and Public Service Motivation. Public Administration Review, [S. l.], v. 76, n. 1, p. 177-187, 2016. DOI: 10/gf4qs8. 
FAULKNER, N. et al. The INSPIRE Framework: How Public Administrators Can Increase Compliance with Written Requests Using Behavioral Techniques. Public Administration Review, [S. l.], v. 79, n. 1, p. 125-135, 2019. DOI: 10.1111/puar.13004.

FERNANDEZ, S.; MOLDOGAZIEV, T. Employee Empowerment, Employee Attitudes, and Performance: Testing a Causal Model. Public Administration Review, [S. l.], v. 73, n. 3, p. 490-506, 2013. DOI: 10.1111/puar.12049.

GHAFFARZADEGAN, N.; ANDERSEN, D. F. Modeling behavioral complexities of warning issuance for domestic security: a simulation approach to develop public management theories. International Public Management Journal, [S. l.], v. 15, n. 3, p. 337-363, 2012. DOI: 10.1080/10967494.2012.725566.

GOLODNIKOVA, A. E.; TSYGANKOV, D. B.; YUNUSOVA, M. A. Potential of using "nudge" concept in state regulation. Voprosy Gosudarstvennogo I Munitsipalnogo Upravleniya-Public Administration Issues, [S. l.], n. 3, p. 7-31, 2018.

GRIMMELIKHUIJSEN, Stephan; JILKE, Sebastian; OLSEN, Asmus Leth; TUMMERS, Lars. Behavioral Public Administration: Combining Insights from Public Administration and Psychology: Public Administration and the Disciplines. Public Administration Review, [S. l.], v. 77, n. 1, p. 45-56, 2017. DOI: 10/f9pbf6.

HASSAN, S.; WRIGHT, B. E. The Behavioral Public Administration Movement: A Critical Reflection. Public Administration Review, [S. l.], v. 80, n. 1, p. 163-167, 2020. DOI: 10.1111/puar.13130.

HONG, Jon-Chao; TAI, Kai-Hsin; HWANG, Ming-Yueh; KUO, Yen-Chun; CHEN, JhihSiang. Internet cognitive failure relevant to users' satisfaction with content and interface design to reflect continuance intention to use a government e-learning system. Computers in Human Behavior, [S. l.], v. 66, p. 353-362, 2017. DOI: https://doi.org/10.1016/j.chb.2016.08.044.

HONG, S. A Behavioral Model of Public Organizations: Bounded Rationality, Performance Feedback, and Negativity Bias. Journal of Public Administration Research and Theory, $[S$. l.], v. 29, n. 1, p. 1-17, 2019. DOI: 10.1093/jopart/muy048.

HONG, S.; KIM, S. H.; SON, J. Bounded rationality, blame avoidance, and political accountability: how performance information influences management quality. Public Management Review, $[S . \quad l],$.$\quad v. 22, n. 8, p. 1240-1263, 2020. DOI:$ 10.1080/14719037.2019.1630138.

JENSEN, U. T.; ANDERSEN, L. B. Public service motivation, user orientation, and prescription behaviour: Doing good for society or for the individual user? Public Administration, [S. l.], v. 93, n. 3, p. 753-768, 2015. DOI: 10/f7rr85.

JONES, B. D. Bounded rationality and political science: Lessons from public administration and public policy. Journal of Public Administration Research and Theory, [S. l.], v. 13, n. 4, p. 395-412, 2003. DOI: 10/dm28qv.

JONES, B. D. Behavioral rationality as a foundation for public policy studies. Cognitive Systems Research, [S. l.], v. 43, p. 63-75, 2017. DOI: 10.1016/j.cogsys.2017.01.003. 
KASDAN, D. O. Nudging the Neoliberal Agenda: Administrative Opportunities in the Deregulated State. Public Administration Review, [S. l.], v. 79, n. 3, p. 439-442, 2019. DOI: 10.1111/puar.13045.

KEISER, L. R.; MILLER, S. M. Does Administrative Burden Influence Public Support for Government Programs? Evidence from a Survey Experiment. Public Administration Review, [S. l.], v. 80, n. 1, p. 137-150, 2020. DOI: 10/gg5zq4.

KIM, S. E. Physical Workplace as a Strategic Asset for Improving Performance in Public Organizations. Administration \& Society, [S. l.], v. 46, n. 5, p. 496-518, 2014. DOI: $10.1177 / 0095399713479104$

KING, S. M. Religion, spirituality, and the workplace: Challenges for public administration. Public Administration Review, [S. l.], v. 67, n. 1, p. 103-114, 2007. DOI: 10/b7gt6c.

LIBERATI, Alessandro. The PRISMA Statement for Reporting Systematic Reviews and MetaAnalyses of Studies That Evaluate Health Care Interventions: Explanation and Elaboration. Annals of Internal Medicine, [S. l.], v. 151, n. 4, p. W, 2009. DOI: 10.7326/0003-4819-1514-200908180-00136.

LIU, X. S.; STOUTENBOROUGH, J.; VEDLITZ, A. Bureaucratic expertise, overconfidence, and policy choice. Governance-an International Journal of Policy Administration and Institutions, [S. l.], v. 30, n. 4, p. 705-725, 2017. DOI: 10.1111/gove.12257.

MEYER-SAHLING, J. H.; MIKKELSEN, K. S.; SCHUSTER, C. The Causal Effect of Public Service Motivation on Ethical Behavior in the Public Sector: Evidence from a Large-Scale Survey Experiment. Journal of Public Administration Research and Theory, [S. l.], v. 29, n. 3, p. 445-459, 2019. DOI: 10/gg5zq3.

MOYNIHAN, D. P.; HAWES, D. P. Responsiveness to Reform Values: The Influence of the Environment on Performance Information Use. Public Administration Review, [S. l.], v. 72, p. S95-S105, 2012. DOI: 10.1111/j.1540-6210.2012.02653.x.

NIELSEN, P. A. Learning from performance feedback: performance information, aspiration levels, and managerial priorities. Public Administration, [S. l.], v. 92, n. 1, p. 142-160, 2014. DOI: 10/f54qnq.

OLIVER, A. Nudging, shoving, and budging: Behavioural economic-informed policy. Public Administration, [S. l.], v. 93, n. 3, p. 700-714, 2015. DOI: 10.1111/padm.12165.

OLSEN, A. L.; HJORTH, F.; HARMON, N.; BARFORTT, S. Behavioral Dishonesty in the Public Sector. Journal of Public Administration Research and Theory, [S. l.], v. 29, n. 4, p. 572-590, 2019. DOI: 10.1093/jopart/muy058.

PERRY, J. L.; HONDEGHEM, A.; WISE, L. R. Revisiting the Motivational Bases of Public Service: Twenty Years of Research and an Agenda for the Future. Public Administration Review, [S. l.], v. 70, n. 5, p. 681-690, 2010. DOI: 10/bdkfrh.

SIEVERT, M.; VOGEL, D.; REINDERS, T.; AHMED, W. The Power of Conformity in Citizens' Blame: Evidence from a Survey Experiment. Public Performance \& Management Review, [S. l.], v. 43, n. 1, p. 53-80, 2020. DOI: 10/gg5zq2. 
SNYDER, Hannah. Literature review as a research methodology: An overview and guidelines. Journal of Business Research, [S. l.], v. 104, p. 333-339, 2019. DOI: 10/ggcpgx.

THALER, Richard H.; SUNSTEIN, Cass R. Nudge: improving decisions about health, wealth, and happiness. Rev. and expanded ed ed. New York: Penguin Books, 2009.

TOBER, Markus. PubMed, ScienceDirect, Scopus or Google Scholar - Which is the best search engine for an effective literature research in laser medicine? Medical Laser Application, [S. l.], v. 26, n. 3, p. 139-144, 2011. DOI: 10/djbk5b.

TORUGSA, Nuttaneeya; ARUNDEL, Anthony. Rethinking the effect of risk aversion on the benefits of service innovations in public administration agencies. Research Policy, [S. l.], v. 46, n. 5, p. 900-910, 2017. DOI: 10/gdnf2b.

TUMMERS, L.; BEKKERS, V.; VAN THIEL, S.; STEIJN, B. The Effects of Work Alienation and Policy Alienation on Behavior of Public Employees. Administration \& Society, [S. l.], v. 47, n. 5, p. 596-617, 2015. DOI: 10/f7dr63.

VLAEV, I.; KING, D.; DOLAN, P.; DARZI, A. The Theory and Practice of "Nudging": Changing Health Behaviors. Public Administration Review, [S. l.], v. 76, n. 4, p. 550-561, 2016. DOI: 10/f8wbk2.

WALKER, R. M.; ANDREWS, R.; BOYNE, G. A.; MEIER, K. J.; O’TOOLE, L. J. Wakeup Call: Strategic Management, Network Alarms, and Performance. Public Administration Review, [S. l.], v. 70, n. 5, p. 731-741, 2010. DOI: 10/dcrhgd.

WANG, Qi; WALTMAN, Ludo. Large-scale analysis of the accuracy of the journal classification systems of Web of Science and Scopus. Journal of Informetrics, [S. l.], v. 10, n. 2, p. 347-364, 2016. DOI: 10/f3rrk3.

WEAVER, R. K. Getting People to Behave: Research Lessons for Policy Makers. Public Administration Review, [S. l.], v. 75, n. 6, p. 806-816, 2015. DOI: 10/f7wpz2.

WEIMER, D. L. When Are Nudges Desirable? Benefit Validity When Preferences Are Not Consistently Revealed. Public Administration Review, [S. l.], v. 80, n. 1, p. 118-126, 2020. DOI: $10 / g g 5 z q$.

ZAMIR, E.; SULITZEANU-KENAN, R. Explaining Self-Interested Behavior of PublicSpirited Policy Makers. Public Administration Review, [S. l.], v. 78, n. 4, p. 579-592, 2018. DOI: $10 / g d v k j 6$.

ZARYCHTA, A.; GRILLOS, T.; ANDERSSON, K. P. Public Sector Governance Reform and the Motivation of Street-Level Bureaucrats in Developing Countries. Public Administration Review, [S. l.], v. 80, n. 1, p. 75-91, 2020. DOI: 10/gg5zqx.

ZOU, Xin; YUE, Wen Long; VU, Hai Le. Visualization and analysis of mapping knowledge domain of road safety studies. Accident Analysis \& Prevention, [S. l.], v. 118, p. 131-145, 2018. DOI: 10.1016/j.aap.2018.06.010. 